\title{
Flowering of Aeschynanthus 'Koral' at Fluctuating and Constant Temperatures
}

\author{
Brooks Whitton'and Will Healy ${ }^{2}$ \\ Department of Horticulture, University of Maryland, College Park, MD 20742 \\ Mark Roh \\ Florist and Nursery Crops Laboratory, USDA-BARC, Beltsville, MD 20705
}

Additional index words. lipstick vine, floral initiation

\begin{abstract}
Stock plants of Aeschynanthus 'Koral' were grown with irradiances of 120 or $240 \mu \mathrm{mol}^{-1} \cdot \mathrm{s}^{-2}$ at $18 / 17$, 24/17, or 30/17C (day/night) under 12-hour thermo- and photoperiods. Tip cuttings from stock plants grown at 18/ 17C flowered earlier than those from stock plants grown at 24/17 or 30/17C when cuttings were forced in a glasshouse under natural days $(23 / 18 \mathrm{C})$. No cuttings from stock plants grown at $30 / 17 \mathrm{C}$ reached the visible bud stage after 86 days, while $93 \%$ of the cuttings forced at $18 / 17 \mathrm{C}$ did reach the visible bud stage. $A$. 'Koral' plants were grown at 18 , 24 , or $30 \mathrm{C}$ in a factorial combination of temperatures at 12-hour thermo- and photoperiods $\left(100 \mu \mathrm{mol} \cdot \mathrm{s}^{-1} \cdot \mathrm{m}^{-2}\right)$. After 8 weeks, only plants grown at $18 / 18 C$ had visible buds. After 18 weeks, plants grown at $24 / 24$ or $24 / 18 C$ had visible buds after having unfolded $=2.5$ times as many leaves as plants grown at $18 / 18 C$. Rapid flowering of $A$. 'Koral' is promoted by constant $18 \mathrm{C}$ under a 12-hour photoperiod.
\end{abstract}

Aeschynanthus are valued for their brilliant red or orange flowers that form in leaf axil or in a terminal cluster (Liberty Hyde Bailey Hortorium, 1976). Saylor (1973) began a breeding program in the late 1960 s to develop compact hybrids. These new hybrids and upright species have attracted new interest in Aeschynunthus as a potted floral crop in the greenhouse industry (Christensen, 1988; Paludin, 1985). A. 'Koral' (syn. Schlatter's Koral) is a hybrid of unknown lineage that was provided by the U.S. Dept. of Agriculture Florist and Nursery Crops Laboratory. This cultivar may have resulted from crosses between $A$. speciosus and A. hildebrandii in Denmark (Lentjes, 1985). 'Koral' was chosen for this project because it is compact and it flowers prolifically, producing brilliant red flowers with maroon stripes. The foliage is not glossy, unlike that of some other cultivars.

The effect of temperature on flowering of Aeschynanthus has not been thoroughly studied. Past research has focused on whether flowering was promoted by either increasing irradiance, temperature, or by photoperiod. Zimmer (1972) grew A. speciosus in a 12-hr photoperiod (incandescent lamps; 3700 lux) at 14, 17,20 , or $23 \mathrm{C}$ nights and $23 \mathrm{C}$ days. After 145 days, vegetative growth increased with increasing night temperature. Only plants at a constant $23 \mathrm{C}$ flowered, but only $20 \%$ of these plants reached anthesis. Zimmer did not consider whether absolute temperature or relative difference between night and day temperatures was involved in the flowering response. Flowering may have been triggered by constant temperatures. Zimmer also found that light quantity was more effective than daylength in promoting early flowering. He concluded that for A. speciosus to flower, high light and high temperature were required. Welander (1984) tested night temperatures of $12,15,18$, or $21 \mathrm{C}$ (day temperatures maximally $4 \mathrm{C}$ higher) and found that days to anthesis of $\mathrm{A}$. speciosus increased with increasing temperature.

In a preliminary study, plants of $A$. 'Koral' grown in growth

\footnotetext{
Received for publication 29 Jan. 1990. Scientific Article no. A-6039, Contribution no. 8200 of the Maryland Agricultural Experiment Station. We acknowledge Maryland Sea Grant College for computer support and the USDA Florist and Nursery Crops Laboratory for graduate assistance and plant material. The cost of publishing this paper was defrayed in part by the payment of page charges. Under postal regulations, this paper therefore must be hereby marked advertisement solely to indicate this fact.

'Graduate student.

'Assistant Professor.
}

chambers at 18/17C day/night initiated flowers before plants grown at $24 / 17$ or $30 / 17 \mathrm{C}$. These results coincided with Christensen's (1988) remarks that vegetative growth of A. hildebrandii takes place at $21 \mathrm{C}$ or above, while flowering occurs at 17 to $18 \mathrm{C}$. Low temperature seemed to be the primary factor triggering rapid flowering of Aeschynanthus.

The objectives of this research were to determine: 1) the flowering response of $A$. 'Koral' to a range of temperatures; 2) whether constant or fluctuating temperatures promote rapid flowering; and 3) whether the light or dark period temperature was critical.

\section{Materials and Methods}

Stock plant treatments (expt. 1). On 23 Nov. 1987, plants of A. 'Koral' were placed in growth chambers at $18 / 17,24 / 17$, or 30/17C ( \pm 1C; day/night) under 12-hr thermo- and photoperiods. Irradiance levels of 120 or $240 \mu \mathrm{mol} \cdot \mathrm{s}^{-1} \cdot \mathrm{m}^{-2}$ were supplied with cool-white fluorescent plus incandescent lamps. Nitrogen at $200 \mathrm{mg} \cdot \operatorname{liter}^{-1}(20 \mathrm{~N}-8.6 \mathrm{P}-16.6 \mathrm{~K})$ was applied weekly. On 13 Jan., fifteen 5-cm tip cuttings were harvested from each chamber. Three cuttings were directly rooted per 0.75-liter pot containing Premix Bx medium (Premier, Pointe Her Pére, Quebec, Canada) under natural photoperiod in a glasshouse (21/18C day/night minimum air temperature). After cuttings rooted, fertilization was resumed. Number of leaves and shoot length were recorded at anthesis of the first flower in the terminal cluster. On 4 Apr. (after 81 days), a floral rating was assigned and the number of leaves and shoot length were recorded on all plants not at anthesis. Floral ratings were assigned as follows: $\mathrm{O}=$ vegetative shoots; 1 = visible bud present; $1.5=$ bud $>1 \mathrm{~cm}$ long; $2=$ anthesis; and $3=$ post-anthesis.

Stock plants grown at $18 / 17 \mathrm{C}$ were discarded due to prolific flowering and lack of vegetative growth. Cuttings from the 24/ 17 and 30/17C chambers were harvested on 9 Mar., 1 Apr., or 23 May. Three cuttings were directly rooted per 0.75 -liter container and grown under natural days in a glasshouse as before. Floral ratings of cuttings were recorded on 1 or 24 June (April and May harvest), at which time cuttings were flowering. Floral rating was analyzed using SAS GLM procedure (SAS Institute, Cary, N.C.).

Stock plant and cutting treatments (expt. 2). On 9 Mar., fifteen 5 -cm cuttings were harvested from stock plants grown at 
$30 / 17$ or $24 / 17 \mathrm{C}\left(240 \mu \mathrm{mol} \cdot \mathrm{s}^{-1} \cdot \mathrm{m}^{-2}\right)$ and directly rooted in pots placed into $18 / 17,24 / 17$, or $30 / 17 \mathrm{C}$ chambers, thus resulting in six treatments. Number of leaves, leaf number of lowest bud, and floral rating were recorded on 3 June, after 86 days, at which time plants were flowering.

Constant vs. fluctuating temperatures (expt. 3). Plants were grown in growth chambers at 18,24 , or $30 \mathrm{C}( \pm 2 \mathrm{C})$ during a 12-hr light period, then plants were transferred to 18,24 , or $30 \mathrm{C}$ for a $12-\mathrm{hr}$ dark period resulting in nine treatment combinations. Irradiance was supplied with daylight fluorescent lamps at $100 \mu \mathrm{mol} \cdot \mathrm{s}^{-1} \cdot \mathrm{m}^{-2}$ at canopy level. Six plants of A. 'Koral' (pruned to three shoots each) were placed in treatments on 12 Jan. A replicate in time began 13 Mar. Fifteen apices from shoots similar to the three left on the pruned plants were dissected and determined to be vegetative at the start of treatment. Number of leaves $>1.5 \mathrm{~cm}$ (from leaf tip to base) were recorded, and the top leaf was notched to allow successive growth measurement.

Data were collected after 18 weeks from the start of treatment. The following data were recorded: number of leaves unfolded $>1.5 \mathrm{~cm}$; node at which the first flower bud appeared (from notched leaf); number of flower buds; and length of longest flower bud. Data were analyzed using SAS GLM procedure.

\section{Results}

Stock plant treatment. The floral rating of the plants established from cuttings increased as day temperature decreased and the temperature differential between day and night temperature decreased (Table 1). Shoot length decreased as day temperature decreased. Doubling the irradiance did not clearly increase floral rating. Forty-seven percent of the cuttings forced from stock plants grown at $18 / 17 \mathrm{C}$ and $13 \%$ of the cuttings forced from stock plants grown at $24 / 17 \mathrm{C}$ reached anthesis, while none of the cuttings forced from stock plants grown at 30/17C flowered. The total number of leaves and shoot length at anthesis showed a temperature by irradiance interaction at 30/17C.

Floral development was advanced at $24 / 17 \mathrm{C}$ compared to $30 /$ $17 \mathrm{C}$ (mean ratings 1.38 vs. 0.39). Floral rating increased over time (considering that the third replication only-rooted 30 days)

Table 1. Vegetative and floral responses of Aeschynanthus 'Koral' plants established from cuttings harvested from stock plants exposed to various temperature and irradiance treatments. Examination 81 days after cuttings were harvested (expt. 1).

\begin{tabular}{|c|c|c|c|c|c|}
\hline \multirow{2}{*}{$\begin{array}{l}\text { Day/night } \\
\text { temperature } \\
\left({ }^{\circ} \mathrm{C}\right) \\
\end{array}$} & & \multirow[b]{2}{*}{$\begin{array}{c}\text { Irradiance } \\
\left(\mu \mathrm{mol} \cdot \mathrm{s}^{-1} \cdot \mathrm{m}^{-2}\right)\end{array}$} & \multicolumn{3}{|c|}{ Stock plant } \\
\hline & & & $\begin{array}{c}\text { Floral } \\
\text { stage } \\
\text { (rating) }\end{array}$ & $\begin{array}{c}\text { Leaves } \\
\text { (no.) }\end{array}$ & $\begin{array}{l}\text { Shoot } \\
\text { length } \\
(\mathrm{cm})\end{array}$ \\
\hline $18 / 17$ & & 240 & 1.3 & 6.6 & 1.5 \\
\hline $18 / 17$ & & 120 & 1.1 & 6.2 & 1.5 \\
\hline $24 / 17$ & & 240 & 0.6 & 7.4 & 1.5 \\
\hline $24 / 17$ & & 120 & 0.7 & 6.6 & 2.2 \\
\hline $30 / 17$ & & 240 & 0.3 & 4.8 & 2.8 \\
\hline $30 / 17$ & & 120 & 0.0 & 6.6 & 2.2 \\
\hline Effect & $\mathrm{df}$ & & \multicolumn{3}{|c|}{ Significance } \\
\hline Temperature & 2 & & $* *$ & $* *$ & $* *$ \\
\hline Irradiance & $\overline{1}$ & & NS & NS & NS \\
\hline Temp $\times$ irrad. & 2 & & NS & $* *$ & $* *$ \\
\hline MSE & 517 & & 0.4 & 9.9 & 1.3 \\
\hline
\end{tabular}

${ }^{\mathrm{z}}$ Floral rating $(\mathrm{O}=$ vegetative, $1=$ visible bud, $1.5=$ flower bud $>1 \mathrm{~cm}, 2=$ anthesis, $3=$ post-anthesis).

$* * \mathrm{X}+$ significant at $\mathrm{P}=0.01$ or nonsignificant at 0.05 , respectively. as stock plants became more floral. After 11 months of growth, all shoots on the stock plants had reached visible bud (data not presented).

Stock plant and cutting treatment. After 86 days, none of the cuttings harvested from stock plants grown and forced at 30/ $17 \mathrm{C}$ had reached the visible bud stage, while $93 \%$ of cuttings forced at $18 / 17 \mathrm{C}$ reached visible bud stage (Table 3). Of the cuttings from stock plants grown at $24 / 17 \mathrm{C}, 93 \%$ or $100 \%$ reached the visible bud stage when forced at $18 / 17$ or $24 / 17 \mathrm{C}$, respectively, while only $33 \%$ reached visible bud stage when forced at $30 / 17 \mathrm{C}$.

Constant vs. fluctuating temperatures. Increasing the day temperature increased internode length, while increasing night temperature decreased internode length (Table 4). When temperatures during the light period were higher than during the dark period, elongation was promoted. When dark period tem-

Table 2. Floral stage of plants that originated from stock plants grown at $30 / 17$ or $24 / 17 \mathrm{C}$ with 12 -hr thermo- and photoperiods. Cuttings were harvested on 9 Mar., 1 Apr., or 23 May and floral ratings were assigned 81,86 , or 30 days later, respectively. Plants were grown in a greenhouse at $21 / 18 \mathrm{C}$ after the cuttings were harvested (expt. 1).

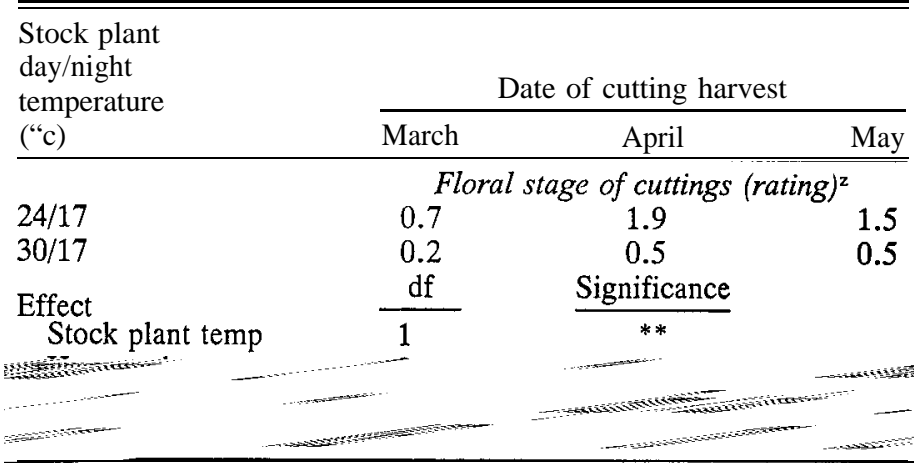

'Floral rating $(\mathrm{O}=$ vegetative, $1=$ visible bud, $1.5=$ bud $>1 \mathrm{~cm}$, 2 = anthesis, 3 = post-anthesis).

** Significant at $P=0.01$.

Table 3. Effect of temperatures at which stock plant and rooted cuttings were grown on vegetative and flowering-response of cuttings 86 days after cutting were harvested. Node of first flower bud was recorded for plants that flowered (expt. 2).

\begin{tabular}{|c|c|c|c|c|c|}
\hline $\begin{array}{c}\text { Day/night tem } \\
\text { Stock plant }\end{array}$ & $\frac{\text { perature }}{\text { Cutting }}$ & $\begin{array}{c}\text { Lẹaves } \\
\text { (no.) }\end{array}$ & $\begin{array}{c}\text { Floral } \\
\text { stage } \\
\text { (rating) }\end{array}$ & $\begin{array}{c}\text { Flowering } \\
\text { plants } \\
(\%)\end{array}$ & $\begin{array}{l}\text { Node of } \\
\text { first } \\
\text { flower bud }\end{array}$ \\
\hline $24 / 17$ & $18 / 17$ & 16 & 1.9 & 100 & 4 \\
\hline $30 / 17$ & $18 / 17$ & 19 & 1.9 & 93 & 5 \\
\hline $24 / 17$ & $24 / 17$ & 20 & 1.8 & 93 & 5 \\
\hline $30 / 17$ & $24 / 17$ & 30 & 1.7 & 20 & 9 \\
\hline $24 / 17$ & $30 / 17$ & 21 & 0.3 & 33 & 7 \\
\hline $30 / 17$ & $30 / 17$ & 27 & 0.0 & 0 & --- \\
\hline Effect & $\underline{\mathrm{df}}$ & \multicolumn{4}{|c|}{ Significance } \\
\hline $\begin{array}{l}\text { Stock plant } \\
\text { Cutting }\end{array}$ & $\begin{array}{l}1 \\
2\end{array}$ & $* *$ & NS & -- & $* *$ \\
\hline Linear & 1 & $* *$ & $* *$ & -.. & $* *$ \\
\hline Quadratic & 1 & $* *$ & $* *$ & $\ldots$ & $* *$ \\
\hline $\begin{array}{l}\text { Stock } \times \text { cut } \\
\text { MSE }\end{array}$ & $\begin{array}{l}2 \\
76\end{array}$ & $\begin{array}{c}\text { NS } \\
29.6\end{array}$ & $\begin{array}{c}\text { NS } \\
0.21\end{array}$ & -- & $\begin{array}{l}\text { NS } \\
2.5\end{array}$ \\
\hline
\end{tabular}

${ }^{2}$ Rating $(0=$ vegetative, $1=$ visible bud, $1.5=$ flower bud $>1 \mathrm{~cm}$, $2=$ anthesis, $3=$ post-anthesis).

$* *, N S$ Significant at $\mathrm{P}=0.01$, or nonsignificant at $P=0.05$, respectively. 
peratures were equal or higher than light period temperatures, elongation was inhibited. Plants grown at $18 / 18$ or $30 / 30 \mathrm{C}$ had unfolded the fewest number of leaves after 18 weeks (Table 5). Flowering was not related to the number of leaves unfolded and plants did not flower after they had unfolded a specific number of leaves.

Flowering was greatly influenced by temperature. After 8 weeks, visible buds were present on $63 \%$ of the shoots in the 18/18C treatment (data not presented). No other treatments had visible buds at this time. After 18 weeks, plants grown at 24/ 24 or $24 / 18 \mathrm{C}$ had visible buds (Table 5) after unfolding $=2.5$ times as many leaves as plants grown at 18/18C. Advanced development of the plants grown at $18 / 18 \mathrm{C}$ was also evident in

Table 4.' Internode length of Aeschynanthus 'Koral' after 18 weeks of treatment at 18,24 , or 30C, day or night (expt. 3). Means were averaged over other treatments.

\begin{tabular}{lcc}
\hline \hline \multirow{2}{*}{ Temperature } & \multicolumn{2}{c}{$\begin{array}{c}\text { Internode length }(\mathrm{cm}) \\
\text { for temperature period }\end{array}$} \\
\cline { 2 - 3 } & Day & Night \\
\hline 18 & 0.5 & 0.6 \\
24 & 0.6 & 0.6 \\
30 & 0.6 & 0.5 \\
Effect & df & Significance \\
Day & 1 & $* *$ \\
$\quad$ Linear & 1 & Ns \\
$\quad$ Quadratic & & $*$ \\
Night & 1 & Ns \\
$\quad$ Linear & 1 & $* *$ \\
$\quad$ Quadratic & 4 & 0.02 \\
Day $\times$ night & 257 & \\
MSE & & \\
** NS Significant at P $=0.01$ or nonsignificant at $P=0.05$, respec- \\
tively.
\end{tabular}

the increased flower bud length and number of flower buds per floral apex.

\section{Discussion}

Gertsson (1987) clearly showed that A. speciosus was photoperiodic. However, because the plant flowered under long and short photoperiods for another researcher (Welander, 1984), A. speciosus should be classified as a facultative long-day plant. Irradiance was shown to modify the flowering response of Aeschynanthus (Zimmer, 1972). Our results (Table 1) suggest that this cannot be the primary trigger for floral induction as previously reported (Zimmer, 1972), because plants flowered at similarly both low and high irradiance. A. speciosus is an understory plant adapted to low light conditions in nature (Burrt and Woods, 1975) and it seems unlikely that the plant would be induced to flower based solely on increasing irradiance. The response to increasing irradiance may have accelerated floral development through a photosynthetic response that can be separated from floral induction (Zimmer, 1972). The results of expt. 1 showed that rapid flowering of $A$. 'Koral' was promoted by equal day/night temperatures that were relatively low (Table 1). A. speciosus grown at the same temperatures as used in expt. 1 flowered similarly (Whitton, 1989). Previous temperature studies (Zimmer, 1972; Welander, 1984) used fluctuating rathr than constant temperatures, which may explain why rapid flowering of A. speciosus did not occur in their low temperature treatments.

Low or constant temperatures were not an absolute requirement for flowering, since all stock plants in expt. 1 and 2 produced flower buds after 11 months (data not presented). This result indicates that fluctuating day/night temperatures at 12-hr photoperiods most likely delays floral initiation and does not cause floral abortion. These results do not conflict with Gertsson's (1987) conclusion that A. speciosus is a long-day plant but may indicate a critical interaction with temperature under $12-\mathrm{hr}$ photoperiods.

Table 5. Vegetative and flowering response of Aeschynanthus 'Koral' after 18 weeks of 12$\mathrm{hr}$ day/night photo- and thermoperiods.

\begin{tabular}{|c|c|c|c|c|c|c|}
\hline $\begin{array}{l}\text { Day/night } \\
\text { temperature } \\
\left({ }^{\circ} \mathrm{C}\right) \\
\end{array}$ & & $\begin{array}{c}\text { Leaves } \\
\text { unfolded } \\
\text { (no.) }\end{array}$ & $\begin{array}{c}\text { Flowering } \\
\text { shoots } \\
(\%)\end{array}$ & $\begin{array}{l}\text { Node of } \\
\text { first } \\
\text { flower bud }\end{array}$ & $\begin{array}{l}\text { Flower buds/ } \\
\text { generative } \\
\text { shoot } \\
\text { (no.) }\end{array}$ & $\begin{array}{l}\text { Length of } \\
\text { longest } \\
\text { flower bud } \\
\text { (mm) }\end{array}$ \\
\hline $18 / 18$ & & 22 & 97 & 12 & 18 & 15 \\
\hline $24 / 18$ & & 34 & 29 & 32 & 4 & 1 \\
\hline $30 / 18$ & & 30 & 0 & $--z^{z}$ & $--{ }^{2}$ & $\ldots 2$ \\
\hline $18 / 24$ & & 36 & 0 & --- & --- & -- \\
\hline $24 / 24$ & & 33 & 72 & 31 & 5 & 1 \\
\hline $30 / 24$ & & 32 & 0 & -- & -- & $\ldots$ \\
\hline $18 / 30$ & & 33 & 0 & -- & $\cdots$ & --- \\
\hline $24 / 30$ & & 33 & 0 & $\cdots$ & $\ldots$ & --- \\
\hline $30 / 30$ & & 26 & 0 & -- & --- & --- \\
\hline Effect & $\underline{\mathrm{df}}$ & \multicolumn{5}{|c|}{ Significance } \\
\hline Temp & 8 & & & $* *$ & $* *$ & $* *$ \\
\hline \multicolumn{7}{|l|}{ Day temp } \\
\hline Linear & 1 & NS & & & & \\
\hline Quadratic & 1 & ** & & & & \\
\hline \multicolumn{7}{|l|}{ Night temp } \\
\hline Linear & 1 & $* *$ & & & & \\
\hline Quadratic & 1 & ** & & & & \\
\hline Day $\times$ night & & NS & NS & NS & NS & NS \\
\hline MSE & 137 & 45.9 & 31 & 28.8 & 9.8 & 76.4 \\
\hline
\end{tabular}

${ }^{2}$ Plants remained vegetative

**,ns Significant at $\mathrm{P}=0.01$ or nonsignificant at $P^{=} 0.05$, respectively. 
Low temperatures (18/17C) induced flowering, while high temperatures maintained vegetative stock plants. Cuttings from stock plants grown at 30/17C and then forced at 18/17C flowered rapidly, while cuttings grown and forced at 30/17C remained vegetative. Initiation and continued floral development may be reversed by high temperatures since only $33 \%$ of the cuttings from stock plants grown at $24 / 17 \mathrm{C}$ reached the visible bud stage when forced at $30 / 17 \mathrm{C}$, while $93 \%$ of the cuttings forced at $24 / 17 \mathrm{C}$ reached this stage.

Growth at $18 / 18 \mathrm{C}$ promoted more rapid flowering than all other temperature combinations at a 12-hr photoperiod (expt. 3). Constant temperatures promoted more rapid and uniform floral initiation than did fluctuating temperatures (Table 5). This conclusion is supported by the plants grown at 24/24C, which had the second greatest number of flowering shoots, while no plants in the $18 / 24 \mathrm{C}$ regime initiated flower buds.

. Because flowering was not directly related to the number of leaves unfolded, it is clear that plant size or age is not directly responsible for flowering. In Zimmer's work (1972), increased growth at elevated temperatures cannot be separated from the flowering response.

Plants held at constant $18 \mathrm{C}$ showed very little shoot elongation and thus were shorter than the other plants. This result is beneficial because past research has indicated a need for the use of chemical growth retardants to control height of Aeschynanthus (Adriansen and Andersen, 1983).

\section{Literature Cited}

Adriansen, E. and H. Andersen. 1983. Influence of fertilization periods, application of Reducymol and Atrinal in two species of Aeschynanthus Tidsskr. Planteavl. 87:167-177.

Burrt, B.L. and J.B. Woods. 1975. Studies in the Gesneriaceae of the old world, XXXIX: towards a revision of Aechynanthus. Notes Royal Bet. Gard. Edinburgh 33:471-489.

Christensen, O. 1988. New pot crops offer new opportunities. BPI News 19(3):10-11.

Gertsson, U.E. 1987. Influence of light on flowering of Aeschynanthus speciosus Hook. J. Hort. Sci. 62:71-74.

Lentjes, P. 1985. Perspectieven voor A. hildebrandii als potplant. Vakblad voor de Bloemisterij 33:56-57.

Liberty Hyde Bailey Hortorium. 1976. Hortus third: A concise dictionary of plants cultivated in the United States and Canada. 3rd ed. Macmillan, New York.

Paludin, N. 1985. Inactivation of tobacco mosaic virus in Aeschynanthus hildebrandii by means of heat treatment, chemotherapy and meristem-tip culture. Tidsskr. Planteavl. 89:273-278.

Saylor, W.R. 1973. Some observations on Aeschynanthus. Gloxinian 23:8-10, 13.

Welander, N.T. 1984. Influence of temperature and daylength on flowering in Aeschynanthus speciosus. Scientia Hort. 22:157-161.

Whitton, B.K. 1989. The effects of temperature and daylength on flowering ofAeschynanthus 'Koral'. MS Thesis, Univ. of Maryland, College Park.

Zimmer, K. 1972. Zum blühen von Aeschynanthus speciosus. Gartenwelt 24:520-521. 